\title{
Modelo narrativo e composição da paisagem em Voyage à l'interieur du Brésil
}

\author{
Narrative model and composition of landscape in Voyage à l'intérieur du Brésil \\ Cristiano Alencar Arrais \\ https://orcid.org/0000-0001-7831-1376 \\ Universidade Federal de Goiás \\ Deusa Maria Boaventura \\ https://orcid.org/0000-0003-4580-817X \\ Pontifícia Universidade Católica de Goiás
}

\begin{abstract}
Resumo: O artigo procura entender as narrativas sobre a paisagem presente na obra Voyage à l'interieur Du Brésil do viajante francês August de Saint-Hilaire, amparando-se na perspectiva que o considera como um intérprete da diferença. Aponta, portanto, o seu projeto de escrita ao enfatizar seu lugar de fala e as distinções entre o seu próprio universo e o que descrevia por meio da expectativa de recepção. Seus escritos sobre a paisagem do interior do território brasileiro, além de expressarem aquilo que o viajante vê, tematizam a dimensão cultural a partir do qual descreve. Com a utilização do conceito de sertão, o viajante modela uma representação do mundo, reorientando o conteúdo semântico do termo. Por último, seu projeto de escrita é orientado pela ênfase na paisagem local, mas principalmente pela memória afetiva do autor que intervém constantemente em sua escrita.
\end{abstract}

Palavras-chave: Saint-Hilaire. Narrativa. Paisagem. Sertão.

Abstract: The article tries to understand the narratives about the landscape present in the work Voyage à l'intérieur du Brésil of the French traveler August de Saint-Hilaire, relying on the perspective that considers him as an interpreter of the difference. He thus points out his writing project by emphasizing his place of speech and the distinctions between his own universe and what he described by expectation of reception. His writings on the landscape of the interior of the Brazilian territory, besides expressing what the traveler sees, thematize the cultural dimension from which he describes. Using the concept of sertão, the traveler models a representation of the world, reorienting the semantic content of the term. Finally, his writing project is guided by the emphasis on the local landscape, but mainly by the affective memory of the author who constantly intervenes in his writing.

Keywords: Saint-Hilaire. Narrative. Landscape. Sertão.

\section{Introdução}

Esse texto toma como objeto de atenção os escritos produzidos por Auguste de Saint-Hilaire em sua passagem pelo interior do Brasil, nas primeiras décadas do século XIX. À mesma época do viajante francês, vieram para o Brasil o príncipe Maximilian Alexander Philip de Wied-Neuwied (1815-1817), Carlos Friedrich Philip von Martius (1817-1820), Johann Moritz Rugendas (1822-1825), dentre outros. Estes escritores, por terem explorado diferentes lugares do Brasil e produzido relatos sobre as paisagens exploradas, são constantemente tomados como importantes referências para os estudos sobre a paisagem local (Süssekind, 1990; Eckardt, 2009; Belluzo, 2000).

Saint-Hilaire, assim como os outros exploradores, tinha um olhar cultivado habilidosamente para a observação da paisagem exótica que encontraria no Brasil e procurava conhecer "cada particularidade da fauna, flora, recursos hídricos e minerais, bem como os costumes de seus habitantes" (Sallas, 2013, p. 13). As obras resultantes de suas viagens tinham os propósitos de registrar o cotidiano dos habitantes do Brasil e buscar dados para o entendimento - seu e de seus leitores - de uma região distinta da Europa 
(Sussekind, 2006, p. 61).

Nesse sentido, pode-se afirmar que, ao descrever a paisagem exótica, Saint-Hilaire acabou por deixar rastros de seu lugar de fala e da diferença entre o seu mundo e aquele que descrevia. Afinal, conforme lembra Hartog (1999, p. 364), "o único sujeito da enunciação, o narrador é o tradutor da diferença: ele é o condutor entre o lá e o aqui - ou póros entre o mundo em que se conta e o mundo que se conta." Nesse sentido, a descrição da paisagem local é a expressão, ao mesmo tempo, de um olhar treinado para buscar o novo (aquilo que vê) e das balizas culturais a partir do qual se descreve o novo. A partir dessa intuição inicial, o objetivo desse trabalho é, em primeiro lugar, identificar as marcas subjetivas externas e internas ao texto de Saint-Hilaire, capazes de situar seu projeto de escrita para além da sua identidade de botânico e naturalista. Isso porque, conforme observou Torrão Filho (2008, p. 46) em sua crítica à historiografia sobre os viajantes estrangeiros, "ao desconsiderar as formas de produção destas narrativas, é grande o risco de se reproduzir os lugares-comuns destes textos como se eles fossem pura descrição do referente, um espelho de uma suposta "realidade" resgatada por instantâneos de experiência de um sujeito que retrata aquilo que observa, com olhos privilegiados de estrangeiro".

Num segundo momento, pretende concentrar-se no entendimento do processo de síntese e de organização da paisagem local, levada a efeito a partir do emprego do conceito de sertão. Por último, busca-se apreender a estratégia descritiva adotada pelo narrador para se referir à paisagem, modelada sobretudo pela memória afetiva que remete à experiência da viagem. Juntos, projeto de escrita, conceito ordenador e memória afetiva formam um trinômio capaz de circunscrever as ideias mobilizadas na narrativa de Auguste de Saint-Hilaire.

\section{Um projeto de escrita}

A oportunidade de Saint-Hilaire conhecer o Brasil apresentou-se quando, em 1816, o conde de Luxemburgo organizou uma comitiva para viajar à América do Sul com o objetivo de mediar o processo de reaproximação diplomática entre França e Portugal. Entre 1823 e 1853 - data de sua morte - parte considerável dos relatos de Saint Hilaire foram publicados na França ${ }^{1}$.

Para Miranda (2007, p. 3) este era um momento especial do processo de expansão econômica europeia, voltado para um aproveitamento mais intenso e eficaz dos recursos disponíveis nas diversas partes do planeta:

os cientistas buscavam produzir conhecimentos capazes de identificar e avaliar esses recursos, oferecendo parâmetros para repensar as relações entre o Velho e o Novo Mundo. Nas instruções das academias aos cientistas viajantes encontramos a recomendação de recolher e aclimatar plantas de lugares longínquos, vegetais que seriam úteis para o comércio das grandes potências ou que ajudariam a resolver o problema da fome dos pobres da Europa.

Essa postura era partilhada por uma extensa lista de exploradores europeus que percorreram regiões do mundo até então inexploradas, influenciados pelo impacto da política externa das nações europeias, pelo entusiasmo missionário, pela curiosidade científica ou, ainda, pela iniciativa jornalística (Hobsbawm, 1982). Muitas vezes financiados pelo Estado, funcionavam como "elos úteis na cadeia que liga as colônias e os lugares ditos "exóticos" aos museus e jardins botânicos europeus" (Kury, 2003, p. 01).

Vinculada a essa explicação contextual, a identidade de Saint-Hilaire como naturalista e botânico foi tomada por muitos autores como critério básico de interpretação para o tipo de descrição que faz da paisagem, como se intencionalmente o viajante se anulasse frente ao relato. O estudo pioneiro de Mary Louise Pratt (1999, p. 99) enfatiza que seus relatos sugerem "a imagem do naturalista como Adão sozinho em seu jardim. Onde, poder-se-ia perguntar, estão todos? A paisagem é descrita como inabitada,

\footnotetext{
${ }^{1} \mathrm{O}$ primeiro volume foi publicado em 1830 e o último volume em 1851. As publicações originais do autor foram digitalizadas e estão disponíveis no link: https://archive.org/search.php?query=creator\%3A\%22Auguste+de+Saint+-Hilaire\%22. Acesso em 08 jun. 2016. Além disso, no Muséum National d'Histoire Naturelle encontra-se a maior parte dos manuscritos da viagem de SaintHilaire, que tratam de seu processo de catalogação do material coletado durante sua passagem pelo Brasil. Quanto aos manuscritos que deram origem à Voyage à l'interieur du Brésil, estes não estão disponíveis.
}

SÆECULUM - Revista de História [v. 24, n. 41]. João Pessoa, p. 111-123, jul./dez. 2019, ISSNe 2317-6725. 
devoluta, sem história, desocupada até mesmo pelos próprios viajantes". Característica semelhante já havia sido apontada por outro estudo basilar, de Süssekind (1990, p. 111): "o 'eu' que narra quase sempre se apaga e o narrador passa a se figurar ora num plural impessoal - 'Nós estrangeiros' -, ora numa imagem genérica, atemporal, a que se chama apenas de 'o viajante'”.

De fato, o pragmatismo e o rigor científico do viajante podem ser percebidos, por exemplo, nas inúmeras referências às observações publicadas ao final de seus escritos, relacionadas à variação térmica dos locais visitados e às plantas encontradas (Figura 1). Essa mesma característica pode ser aferida na lista de coleções que foram enviadas ao Museu de História Natural e à Real Academia de Ciências da França, dentre as quais destacam-se: 129 espécies de animais mamíferos; 2005 espécies de aves; 35 espécies de repteis; 58 espécies de peixes; 16.000 exemplares de insetos; herbário de aproximadamente 30.000 peças, além de um "grande número de pacotes de sementes" (Saint-Hilaire, 1945, p. 361).

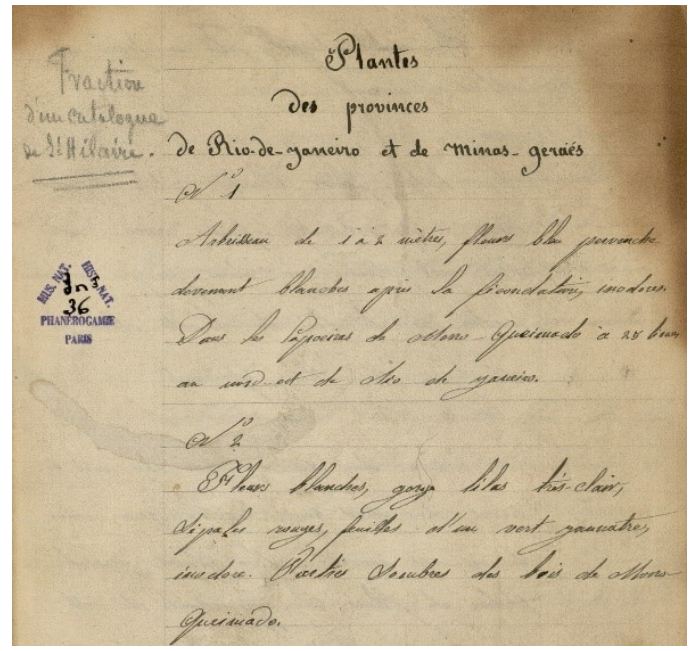

Figura 1: Detalhe de um dos cadernos de campo de Saint-Hilaire com descrições das espécimes coletadas. Caderno de campo A1. Disponível em: http://hvsh.cria.org.br/works. Acesso em 12 de novembro 2018.

Além disso, na reconstrução do itinerário do francês em suas viagens podemos dimensionar o trabalho de coleta e observação da paisagem. Seu itinerário estabelece um percurso de aproximadamente 15.000 quilômetros, ao longo de seis anos no Brasil: o vale do Paraíba, a província de Minas Gerais, especialmente a região de mineração, o Distrito Diamantino, o Vale do Jequitinhonha e o norte da província, o Vale do Rio Doce, o litoral do Rio de Janeiro e o Espírito Santo. Retornou a Minas Gerais pela parte sul, atingindo Araxá. Percorreu ademais, a província de Goiás, retornou a Minas pelo Triângulo Mineiro, atingindo São Paulo, depois o Paraná, Santa Catarina e Rio Grande do Sul. Sua última viagem foi, novamente, em direção a Minas Gerais, até São João del Rei (Versani, 2000).

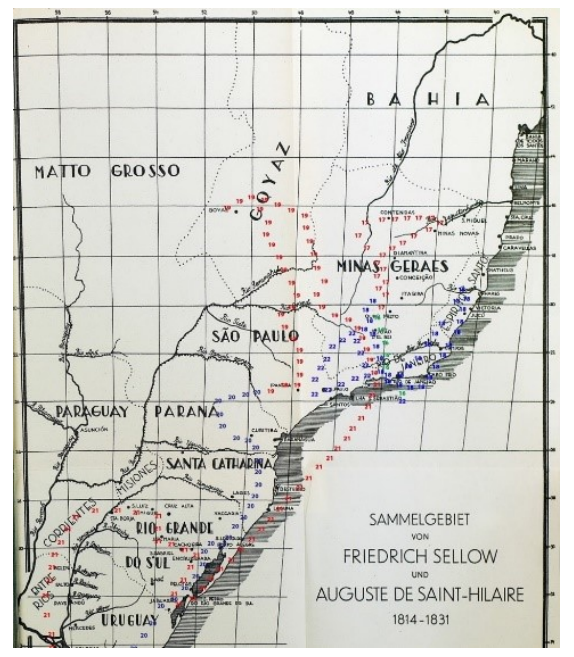

Figura 2: Herter, W. Auf den Spuren der Naturforscher Sellow und Saint-Hilaire 1945. Disponivel em: http://hvsh.cria.org.br/caderno?herter. Acesso em 11 junho de 2018

Por outro lado, é preciso ressaltar que Saint-Hilaire tinha noção da importância da sua viagem e de seus escritos, para além da sua contribuição para a ciência, como enfatizam tais interpretações. Mesmo antes da viagem ao Brasil, Saint-Hilaire já estava integrado ao meio científico europeu - já 
desenvolvia atividades de botânico e era professor do Museu de História Natural de Paris, tendo publicado seu primeiro trabalho em 1811, Réponse aux reproches que les gens du mond font à l'étude de la Botanique. Além disso, seus relatos foram publicados ao longo de 27 anos e apresentam marcas de reescritas e incorporações bibliográficas posteriores ao período que esteve no Brasil, reforçando a percepção de que o autor era extremamente "sensível a publicação dos resultados de seus trabalhos nos melhores jornais e revistas de sua época, especialmente àqueles ligados à Academia e ao Museu ou à Sociedade Filomática e o quanto ele julgava indispensável que as descrições publicadas fossem rigorosas" (Sarthou et al, , 2016, p. 162). Por último, Saint-Hilaire não só sabia que o Museu de História Natural de Paris seguia de perto os passos de suas viagens, por meio das correspondências enviadas por ele, como usaria esse empreendimento como capital simbólico para identificar sua trajetória intelectual. Comprovam isso os argumentos utilizados pelo autor para pleitear sua admissão à Academia de Ciências de Paris, em 1828 e 1830:

Espero também, senhor, que uma viagem de mais de seis anos, um trabalho imenso, os sacrifícios mais dolorosos vos parecerão dignos de uma recompensa. Nada seria mais lisonjeiro para mim que obter vosso voto $[\ldots]$.

Vinte e cinco anos consagrados à botânica, duas grandes obras começadas; uma longa sequência de memórias, das quais muitas submetidas à Academia; seis anos de viagens no Brasil, na República Cisplatina e nas missões, os dois primeiros volumes dessas viagens atualmente no prelo: estes são, Sr., meus títulos à cadeira vaga ${ }^{2}$.

Estamos diante, portanto, de um indivíduo que não esconde em nenhum momento, o juízo que faz de si dentro da comunidade científica francesa.

Acerca do processo de edição de suas obras, muito embora tenhamos poucas informações a esse respeito, vale lembrar que a publicação das obras dos viajantes situa-se no interior do movimento de tradução cultural, do exótico (a América), para um código cultural reconhecível (a Europa). Elas foram influenciadas pela "conjugação de determinados modelos vigentes à época de sua elaboração e que se cristalizam como expressão de regras a perpassar tanto a elaboração dos desenhos e dos esboços, quanto do quadro acabado e impresso num livro" (Sallas, 2013, p. 416).

De modo semelhante, é possível identificar os indícios da aproximação entre texto e público receptor no decurso da edição das obras de Saint-Hilaire, inicialmente, a partir do "esforço de assimilação de dados e representações a respeito do Brasil presentes em obras que circulavam nos meios literários e científicos europeus" (Miranda, 2009, p. 623). Saint-Hilaire assim se posiciona sobre a composição de sua escrita e o modelo de apresentação que opta para dirigir sua narrativa sobre a Província de Goiás:

Por força das observações críticas feitas por mim, visando a alcançar o fim a que me propunha, este livro apresenta um número talvez excessivo de notas, cuja leitura, aliada à do texto, será sem dúvida cansativa em alguns pontos. É aconselhável, pois, que o leitor deixe de lado as notas, para lê-las ao fim de cada capítulo. A fim de facilitar a consulta, tive o cuidado de indicar as notas de crítica no quadro geral, sob o título Retificações. (Saint-Hilaire, 1975, p. 15)

É importante ressaltar que essa relação dialógica com o público leitor era procedimento padrão desse tipo de obra. Johann Emanuel Pohl, por exemplo, em Viagem no Interior do Brasil, publicado em 1832, explicita a relação que procurava construir com seus leitores, bem como a expectativa de recepção da obra:

Este diário é destinado a todas as espécies de leitores e, para torná-lo mais atrativo àqueles que, por sua tendência e pendor, pouca inclinação poderiam ter por sua parte estritamente científica e pela coleta feita para as ciências naturais propriamente ditas, resolveu o Autor separar a narração pitoresca, que oferece naturalmente interesse geral, e apresentar à parte tudo o que é rigorosamente científico. (Pohl, 1976, p. 14)

Procedimento de modelação narrativa semelhante pode ser encontrado na apresentação da obra

\footnotetext{
${ }^{2}$ Carta a Henri de Blainville, citada por Sarthou et all, 2016, p. 195. Carta a Bainville, em janeiro de 1830, citada por Kury (2003, p. 07).
} 
de George Gardiner, Viagem ao Interior do Brasil, de 1846:

Foi sua preocupação traçar um quadro, quanto possível fiel, do aspecto físico e produções naturais da região, com umas rápidas observações sobre o caráter, os costumes e a condição das diferentes raças indígenas ou não, que compõem a população das partes visitadas. (Gardiner, 1975, p. 17)

As declarações de Saint-Hilaire, Pohl e Gardiner são evidências fortes sobre o potencial de modelação dos escritos desses viajantes frente ao horizonte de expectativas de seu público. Acompanhavam assim uma tendência generalizada, presente inclusive no personagem mais icônico da geração de viajantes naturalistas, Alexander von Humboldt: "Quero que a viagem esteja escrita de modo a atrair as pessoas de bom gosto" (Prieto, 2003, p. 19) ${ }^{3}$. Esse aspecto foi intensamente examinado por Torrão Filho (2008, p. 260), para quem observa-se o "caráter identitário presente nestes relatos, importantes também para a formação de uma auto-imagem de britânicos e franceses, que encontraram na América luso-brasileira um espelho conveniente para a construção de sua própria identidade".

Poder-se ia falar, portanto, num repertório relativamente comum a esses viajantes, que abarcaria, inclusive, o sistema de normas extra-literárias que estruturam o pano de fundo de suas obras, constituído pelo público receptor. Sobre esse tema, Jauss (1994) lembra que o saber prévio do leitor, seu "horizonte de expectativas", tem a capacidade de determinar a recepção de um texto. Ele é responsável pela primeira reação do leitor à obra e é produzido a partir do conjunto de normas ideológicas e estéticas próprias de sua época, levando à satisfação (conformidade) ou ao estranhamento (ruptura com certo horizonte de expectativas $)^{4}$. Daí porque, paralelamente à estrutura dialógica e também de acordo com esse horizonte de expectativa, em Viagem às Províncias do Rio de Janeiro e Minas Gerais, Saint-Hilaire reafirma o corolário da neutralidade científica de seus escritos lembrando ao leitor que "Levei o escrúpulo da exatidão ao máximo; e, devo confessá-lo, preocupei-me mais em pintar corretamente o que observei do que em burilar o estilo" (1975, p. 04).

Tratava-se, portanto de evidenciar a diferença entre a narrativa minuciosa, exata e escrupulosa, esperada do botânico, mas que pouco se interessou pelos fragmentos que Saint-Hilaire publicou na Nouvelles Annales des voyages (Marcil, 2016, p. 302), da narrativa destinada a um público mais amplo, qualificado de "público culto" ou de "opinião ilustrada", conforme os termos anteriormente utilizados por Humboldt.

Vale lembrar ainda que a narrativa do botânico francês vê-se comprometida com um procedimento de escrita mais complexo que o simples processo de reescrita dos manuscritos originais. Trata-se de um projeto de escrita que teve como matéria-prima suas anotações de viagem, mas que se distingue das mesmas. "Ao mesmo tempo em que o viajante fala do lugar visitado, reelabora o seu próprio lugar de origem, permanecendo em constante diálogo com as suas referências, que podem ser revistas, negadas ou reiteradas. A narrativa sobre o 'outro' também é, afinal, a narrativa sobre 'si mesmo'”, alertou Lisboa (1997, p. 47). Em outras palavras, o projeto de escrita de Saint-Hilaire evoca, além dos seres, contextos e ambientes narrados, a dimensão da introspecção, autoral do narrador bem como o leitor projetado,

\footnotetext{
3 Humboldt produziu uma fórmula narrativa que unia a ideia de missão científica com viagem contemplativa da natureza, entendida como um refúgio para as almas angustiadas. Além da evidente influência do romantismo alemão e do empirismo. A influência da obra de Humboldt, convertido em cânone dos relatos de viagem, pode ser observada em toda a América Latina, como por exemplo nos relatos de viajantes ingleses ao território argentino, conforme observou Prieto (2003).

${ }^{4}$ Hans Robert Jauss é um crítico literário ligado à estética da recepção. A partir da crítica às duas principais correntes teóricas da crítica literária do século XX, o formalismo (compreende o leitor como sujeito da percepção, "como alguém que, seguindo as indicações do texto, tem a seu cargo distinguir a forma ou desvendar o procedimento", construindo um leitor ideal, dotado da compreensão teórica do filólogo") e a marxista (que propõe a análise dos textos literários a partir do exame da posição social do autor ou procura identificar o mesmo dentro do processo de estratificação social a partir da relação base-superestrurura), por ignorarem o papel do destinatário, do público leitor. Para o autor a obra literária é marcada por seu caráter dialógico entre literatura e leitor: "a relação entre literatura e leitor possui implicações tanto estéticas quanto históricas. A implicação estética reside no fato de já a recepção primária de uma obra pelo leitor encerrar uma avaliação de seu valor estético, pela comparação com outras obras já lidas. A implicação histórica manifesta-se na possibilidade de, numa cadeia de recepções, a compreensão dos primeiros leitores ter continuidade e enriquecer-se de geração em geração, decidindo, assim, o próprio significado histórico de uma obra e tornando visível sua qualidade estética. Se, pois, se contempla a literatura na dimensão de sua recepção e de seu efeito, então a oposição entre seu aspecto estético e seu aspecto histórico vê-se constantemente mediada, e reatado o fio que liga o fenômeno passado à experiência presente da poesia, fio este que o historicismo rompera" (Jauss, 1994, p. 23).
} 
interessado instruir-se, entreter-se, mas também em apreender a diferença, mesmo que fosse a partir dos marcadores conceituais e das hierarquizações próprias do Velho Continente (Gadenne, 2003; Torrão Filho, 2008).

\section{O conceito ordenador: sertão}

O termo sertão talvez seja a principal categoria explicativa do interior do território brasileiro até meados do século XX, como destacou Janaina Amado (1995, p. 148) o termo, legado dos colonizadores, foi "uma categoria carregada de sentidos negativos, que absorveu o significado original, conhecido dos lusitanos desde antes de sua chegada ao Brasil" que se constituiu em oposição ao litoral. Essa é a relação dicotômica, reforçada pela trajetória percorrida pelo pensamento social brasileiro em seu processo de modernização (Souza, 1997; Lima, 1999).

Contudo, a história desse conceito revela também o longo processo de constituição e adensamento conceitual, as distintas camadas de atribuição de sentido pelo qual o termo foi submetido até sua elaboração no século XX. De modo sintético, é possível afirmar que tal conceito foi formulado a partir de uma atribuição do "Outro", feita por um "Nós": portugueses, paulistas, funcionários do Império, viajantes estrangeiros, inteligentsia nacionalista etc. Ao longo do processo de atribuição de sentido, preserva-se uma característica comum, encoberta por sua pequena variação morfológica: sertão nunca foi compreendido como uma denominação geográfica, mas sim espacial, conforme mencionado por Moraes (2003).

Partindo dessas considerações iniciais e recorrendo às reflexões desenvolvidas no âmbito da história dos conceitos (Koselleck, 2002, 2006) ${ }^{5}$ pode-se destacar uma característica importante do conceito de sertão, fartamente utilizado na documentação. De fato, é possível observar uma sensível modificação semântica, desde aquelas acepções encontradas entre mapas e escritos do século XVIII. Num primeiro momento, a mobilidade da atribuição geográfico do termo "sertão" na cartografia, acompanha o próprio processo de conhecimento e ocupação branca do interior do território: o "sertão" é sempre uma atribuição às regiões que estão "mais além" - parcial ou totalmente desconhecidas, cercadas de riquezas, mas também de selvagens: "certão do gentio Acruã", "certão do gentio Xavante", "certão do gentio Aricá", entre nove denominações que constam no Mappa dos sertões que se comprehendem de Mar a Mar entre Capitanias de S. Paulo, Goyazes, Cuyabá, Mato-grosso e Pará, ou a Planta de huma grande parte do sertão de Tibagy que se acha descoberto, ambos de meados do século XVIII (Biblioteca Nacional, 2018).
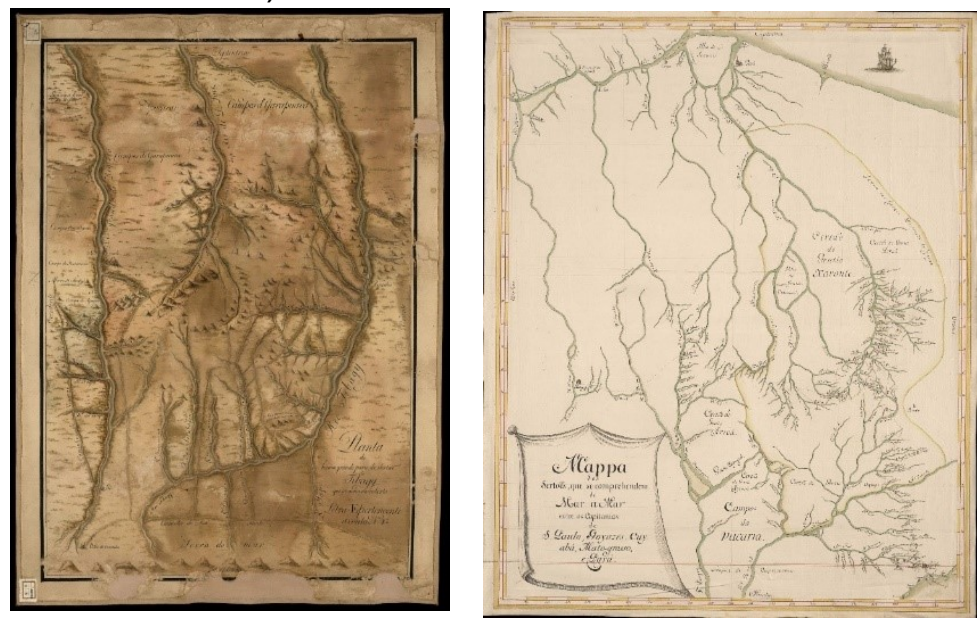

Figura 3: exemplos da cartografia do século XVIII, com a identificação de territórios denominados de sertão. Disponível em: http://bndigital.bn.gov.br/acervodigital. Acesso em 13 novembro de 2018

Já Luiz Maria da Silva Pinto, em seu Diccionario da Lingua Brasileira, publicado em 1832, o termo é compreendido apenas como "O interior das terras; Mato distante da costa marítima". Do mesmo modo,

\footnotetext{
${ }^{5}$ Os objetivos e propósitos principais dos praticantes da história conceitual podem ser encontrados nas obras de seu expoente, Reinhart Koselleck, cujo trabalho foi amplamente debatido na historiografia, motivo pelo qual esse artigo se abstém de sintetizálo.
} 
o Dicionário da Língua Portuguesa Caudas Aulete registrava sertão como "o ponto ou sítio mais afastado dos terrenos cultos; matto longe da costa" (Caudas Aulete, 1881, p. 1641). Por último, no início do século XX, o Novo Dicionário da Língua Portuguesa, designa o sertão como um "Lugar inculto, distante de povoações ou de terrenos cultivados. Floresta, no interior de um continente, ou longe da costa" (Figueiredo, 1913, p. 1851).

A mínima variação semântica acima descrita está em descompasso com a acepção desenvolvida por Saint-Hilaire, bem como por outros viajantes que descreveram o sertão. Para o viajante francês, o sertão é caracterizado menos pela ausência de pessoas e mais pela fragilidade dos laços que unem a vida humana existente nessas regiões a determinado padrão de civilização. Em sua cunhagem observase uma característica teleológica, na medida em que projeta o processo de ocupação do espaço. O sertão é, assim, o deserto espacial, o vazio demográfico, desabitado pela ocupação branca, e também, um espaço à espera de civilização, de progresso:

Se alguns exemplares dos meus relatos resistirem ao tempo e ao esquecimento, as gerações futuras talvez encontrem neles informações de grande interesse sobre essas vastas províncias, provavelmente transformadas, então, em verdadeiros impérios. E ficarão surpreendidas ao verificarem que, nos locais onde se erguerão então cidades prósperas e populosas, havia outrora apenas um ou dois casebres que pouco diferiam das choças dos selvagens; que onde estarão retinindo nos ares os ruídos dos martelos e das máquinas mais complexas ouviam-se apenas, em outros tempos, o coaxar de alguns sapos e o canto dos pássaros; que em lugar das extensas plantações de milho, de mandioca, de canade-açúcar, e das árvores frutíferas, o que havia eram terras cobertas de vegetação exuberante mas inútil. Diante dos campos cortados por estradas de ferro, e talvez mesmo por veículos mais possantes do que nossas locomotivas de hoje, as gerações futuras sorrirão ao lerem nos livros que houve um tempo em que o viajante podia considerar-se afortunado quando conseguia percorrer, numa jornada, quatro ou cinco léguas. (Saint-Hilaire, 1975, p. 14)

A dimensão teleológica desse conceito é reforçada pelos termos indicadores da dicotomia entre dois tempos. No futuro da província de Goiás projeta-se o presente das sociedades europeias: cidades, maquinarias, plantations, estradas de ferro. A mesma expectativa de câmbio pode ser vislumbrada nos escritos de George Gardiner: as privações relatadas pelo viajante "mal podem ser avaliadas pelos que a elas nunca se aventuram [...] separado, por anos, de toda a comunhão civilizada, dormindo meses a fio ao relento; cercado em todas as estações do ano por feras e hordas de índios selvagens" (Gardiner, 1975, p. 17). Também Johann Emanuel Pohl, chega à conclusão semelhante sobre o interior do território brasileiro: "A maior parte da Capitania de Goiás encontra-se inculta e, por isso, é improdutiva, achandose entregue às tribos e índios selvagens e aos animais bravios" (Pohl, 1976, p. 123). Aqui, o olhar pelo viés econômico - o corolário fisiocrata do trabalho agrícola como a verdadeira fonte de riqueza está aqui vazado pela ótica da escola clássica - projeta o padrão de desenvolvimento europeu na América: a cidade, a indústria, a agricultura.

No interior desse processo descritivo e construtivo da paisagem local, importa pouco se os vestígios da presença humana são continuamente apresentados em suas narrativas por meio de antigas regiões de mineração, pontes, fazendas, regiões de cultivo e pasto, ciganos etc. Vencidos pela imposição conceitual, esses vestígios no presente atuaram como prova da grandeza pretérita e da necessidade de uma intervenção do Estado Nacional para a construção das regiões do interior do país (Arrais \& Sandes, 2013). De fato, essa nova cunhagem foi adotada pelos administradores da província de Goiás. Em $A$ província de Goyaz na Exposição Universal, escrito por Alfredo de Escrangnolle Taunay, de 1876, por exemplo, registra-se a acepção já cristalizada que produz uma relação necessária com a ideologia liberal: "sertão no Brazil quer dizer terreno ainda não de todo ganho ao trabalho e á civilisação" (Taunay, 1876, p. 07).

Esse incremento ideológico, cuja gênese encontra-se registrada em Saint-Hilaire, será reforçado ao final do século XIX pelo pensamento social brasileiro. Seguindo caminho distinto da formalização conceitual, ele construirá, a partir do registro formal, uma dicotomia explicativa da falta de progresso do interior, mas também de seu potencial, conforme a ideia do viajante francês: a dicotomia Litoral-Sertão (Souza, 1997; Lima, 1999). 


\section{A paisagem local e a memória afetiva}

A bagagem conceitual de Saint-Hilaire e a expectativa de recepção de seus escritos direcionam a escrita do viajante para os limites da geografia e da etnologia. O registro de suas impressões sobre a paisagem local é constantemente marcado pela "soberba solidão" (Saint-Hilaire, 1975, p.88).

Essa descrição impressonista da paisagem é resultado do modelo narrativo que desenvolve em seus textos. Esse modelo é caracterizado, em primeiro lugar, pela descrição dos itinerários, seguindo o princípio conhecido do diário de viagem: a descrição geográfica das suas localizações com a indicação, sempre que possível, de suas latitudes e longitudes. Na sua impossibilidade, o narrador toma como referência os elementos da natureza. Localiza os povoados a partir dos acidentes geográficos mais destacados:

Aprazivelmente situado numa encosta, acima de um extenso vale, o Arraial de Santa Luzia estende-se paralelamente à margem direita de um riacho que passa no fundo do vale e tem o nome de Córrego de Santa Luzia. O arraial é cortado em duas partes desiguais, no sentido de sua largura, por um córrego menos volumoso, que vai desaguar no primeiro. (Saint-Hilaire, 1975, p. 25)

A localização é geralmente precedida de uma indicação da paróquia a que pertenciam os arraiais e, às vezes, acompanhada do número de habitantes. Jaraguá, escreve, "[...] é uma capela filial de Meia Ponte, contando com cerca de 2.000 fiéis" (Saint-Hilaire, 1975, p. 42). Acrescem à descrição situacional, observações sobre os sítios urbanos. Nesse caso, seu olhar dirige-se para a configuração do traçado, as tipologias residenciais e sua relação com a paisagem local.

Esse olhar recortado está mediado pela cultura barroca: as ruas regulares e largas chamam a sua atenção por ser um princípio de organização espacial próprio de cidades modernas, ou seja, de lugares que obedeciam a um tipo de planejamento e de ordem, onde operava a razão (Saint-Hilaire, 1975, p. 36). É, nesse sentido, um olhar de paisagista, dada a ênfase nas descrições panorâmicas:

Da praça onde fica situada essa igreja [Nossa Senhora do Rosário] descortina-se um panorama que talvez seja o mais bonito que já me foi dado apreciar em minhas viagens pelo interior do Brasil. A praça foi construída sobre um plano inclinado, abaixo dela veem-se os quintais, como os cafeeiros, laranjeiras e bananeiras de largas folhas; uma igreja que se ergue um pouco mais longe contrasta, pela brancura de suas paredes, com o verde-escuro da vegetação; à direita há também casas e quintais, e ao fundo outra igreja; à esquerda vê-se uma ponte semidesmantelada, com um trecho do Rio das Almas coleando por entre as árvores; do outro lado do rio avista-se uma igrejinha rodeada por uma pequena mata, com grupos de árvores raquíticas mais além, confundindo-se com ela. Finalmente, a cerca de légua e meia do arraial o horizonte é limitado ao norte por uma cadeia pouco elevada, que constitui um dos prolongamentos dos Montes Pirineus. (Saint-Hilaire, 1975, p. 36)

Sua descrição considera a distância, a perspectiva e a profundidade; a paisagem de Meia Ponte é descrita a partir dos seus diversos fragmentos; o Rio das Almas, o Monte Pirineus e a mata vão sendo marcados figurando uma paisagem pitoresca da cidade. Para Fonseca (2008, p. 314), Saint-Hilaire incorpora o conceito de pitoresco, oriundo da estética do século XVIII, enfatizando as noções de irregularidade e rudeza das formas: a variedade, o inusitado, inesperado, a dissimetria, a ruptura das formas pelo jogo de luz e sombra seriam, assim, qualidades essenciais da "composição pitoresca", a qual consistiria em unir, num conjunto, uma diversidade de elementos - essencialmente "objetos rudes". Percebe-se que a natureza ocupa espaço central na narrativa de Saint-Hilaire, não somente em função de seus interesses específicos de botânico, como também em razão de sua opção estética. Uma natureza que os homens "percebem com os sentidos, apreendem com o intelecto, modificam com o agir" (Argan, 2010, p. 17).

Somando-se às observações das inúmeras doenças que assolavam as populações locais do interior do Brasil, Saint-Hilaire ecoa princípios que se tornavam clássicos para o nascimento do urbanismo: a condição climática - fator de agravamento da situação dos povoados que visitava - era importante reivindicação de qualidade de vida nas cidades modernas. Suas palavras relacionadas aos aspectos geográficos de Vila Boa atestam este entendimento: 
A cidade construída numa baixada, onde o ar não circula como nas montanhas e nas planícies; onde a água parece pouco salubre e o calor é quase sempre sufocante durante a seca; onde enfim, a umidade deve ser muito grande na estação das chuvas, essa repito, não pode ser propícia aos homens de nossa raça. Essa é uma razão por que os habitantes de Vila Boa estão longe de apresentar uma aparência de saúde, vigor e energia. (Saint-Hilaire, 1975, p.51)

Como se nota na citação acima, sua palheta não exclui o elemento humano. Pelo contrário, como vimos na própria ordenação da paisagem descrita, efetivada por meio do conceito de sertão, a presença humana é constantemente evocada para enfatizar a miséria e as doenças da população local. Além do julgamento das condições locais, tão inadequadas ao "nós" de sua escrita, em vários outros fragmentos, observa-se também o destaque à condição moral das populações locais: a indolência, a preguiça, a pobreza e a promiscuidade. Mesmo na aprazível Meia Ponte existia um "[...] prodigioso número de mendigos que vagueiam pelas ruas do povoado" (Saint-Hilaire, 1975, p. 38). Segundo o viajante, a miséria, ao se estabelecer, embrutecia e provocava desânimo e apatia nas pessoas. "E esta chegou a tal ponto, em muitos deles, que, dispondo praticamente de toda a terra que lhes convém, eles não chegam a cultivar o suficiente nem mesmo para o seu sustento" (Saint-Hilaire, 1975, p. 27). Saint-Hilaire não foi o único viajante a enfatizar esse tipo de matiz moral. Também Pohl descreveria as populações do interior do Brasil como sendo formadas por indivíduos avessos ao trabalho, sendo esses, em especial, mestiços.

Este último dado é recorrente na narrativa dos viajantes. Além da hospitalidade com que recebem os viajantes estrangeiros - compreensível principalmente em razão das cartas de recomendação que traziam consigo - a mestiçagem é fator de destaque. Pohl, por exemplo, afirma que, em Trairas, "os moradores são na maioria negros e mulatos, que também se encontram em grande número nas vizinhanças [...] são de boa índole, corteses e atenciosos e todos foram solícitos em satisfazer os meus pedidos" (Polhl, 1976, p. 194). Na narrativa de Saint- Hilare (1975, p. 51) percebe-se a mesma ênfase, mas com um julgamento oposto: "os negros e os mulatos formam a maior parte da população de Goiás" e muitos deles, como os do arraial de Pilões, não se animavam a trabalhar com a agricultura que poderia livrá-los da pobreza, da vida precária e, portanto, da enorme fragilidade. Esta mesma fragilidade se estendia ainda à vida social das diversas cidades, onde reinava uma completa falta de comunicação (Saint- Hilaire, p. 52).

Dando forma a esse modelo está a memória afetiva de Saint-Hilaire que elege, por exemplo, a Província de Minas Gerais como horizonte comparativo para a descrição de todos os outros locais visitados,

onde tamanha foi a benevolência com que me acolheram que acabei por me identificar com os interesses de seus habitantes. Achava-me quase na posição de um mineiro que, após ter terminado os estudos em sua terra, tivesse desejado conhecer também outras partes do Brasil. A Província de Minas é uma espécie de padrão, por assim dizer, do qual me sirvo para julgar todas as outras que percorri mais tarde. (Saint-Hilaire, 1975, p. 13)

Esse tipo de vínculo emocional não parece ter sido incomum aos viajantes, na medida em que pode ser encontrado um registro semelhante em Pohl (1976, p. 114), em relação ao pequeno povoado de Santa Luzia - "Confesso não ter sido sem lágrimas que me despedi do digno sacerdote, cuja bondade tornara tão agradável a minha estada em Santa Luzia". No caso de Saint-Hilaire, percebe-se que a comparação não é utilizada para definir o nível de desenvolvimento civilizacional dos povoados. Não se trata, portanto, de um princípio de inversão que faz com que o leitor, pelos olhos do viajante, vislumbre a alteridade do Novo Mundo, muito embora, como ressaltou Fonseca (2016), isso também possa ser encontrado em sua narrativa. Trata-se sim de uma afinidade eletiva que se alimenta das lembranças das experiências vividas, sendo fixada na escrita.

Nesse sentido, em que pese o interesse legítimo na descrição detalhada da paisagem, bem como o impulso classificador do viajante, sua narrativa não tem nada de impessoal. Pelo contrário, para o viajante francês, o exercício da escrita atenua os perigos da solidão, conforme lembra Foucault (1992, p. 129) "o facto de se obrigar a escrever desempenha o papel de um companheiro, ao suscitar o respeito humano e a vergonha; [...] aquilo que os outros são para o asceta numa comunidade, sê-lo-á o caderno 
de notas para o solitário". O registro da solidão do viajante é reforçado pela comunicação fragmentária, episódica ou simplesmente impedida entre o narrador e as populações locais:

Enquanto descrevia e examinava as plantas, aproximou-se um homem do rancho, permanecendo várias horas a olhar-me, sem proferir qualquer palavra. Desde Vila Boa até Rio das Pedras tinha eu tido quiçá cem exemplos dessa estúpida indolência. Esses homens, embrutecidos pela ignorância, pela preguiça, pela falta de convivência com seus semelhantes, e, talvez, por excessos venéreos prematuros, não pensam: vegetam como árvores, como as ervas dos campos. (Saint-Hilaire, 1972, p. 95)

De fato, a decadência, a preguiça, a pobreza, os espaços desérticos são fortemente expressos na narrativa de Saint-Hilaire. Todavia é a solidão - não apenas como sinônimo de "vazio" espacial, mas principalmente de apartamento e introspecção pessoal - que delimita e media o alcance de suas percepções sobre a paisagem descrita e seus habitantes. Saint-Hilaire estava verdadeiramente sozinho: raras são as ocasiões em que refere-se a um longo diálogo com os habitantes do interior do Brasil, muito embora nunca estivesse apartado da convivência humana. O limite da busca por informações é apenas ocasionalmente ultrapassado. Guias, batedores e carregadores que o acompanham raramente são mencionados, confundem-se com a paisagem que são, enfim, o verdadeiro motivo de apreciação e lembrança. Mesmo Firmiano, seu auxiliar botocudo que serviu-o em muitas viagens, nunca ultrapassou os limites de fonte de observação e imposição cultural.

Sua escrita, produzida mais de vinte anos após a experiência em território brasileiro, não esconde enfim, as marcas do autor. Ao redigir o prefácio de sua Viagem à Província de Goiás, já em Paris, em 1848, o viajante escreve, nostalgicamente: "Procurei esquecer o presente, tão doloroso para mim, e me vi em imaginação sob o belo céu do Brasil, numa época em que, ávido de conhecimentos, eu percorria os sertões desse país quase tão descuidado do futuro quanto seus próprios indígenas" (Saint-Hilaire, 1975, p. 13).

\section{Considerações Finais}

Os três elementos destacados nos permitem reconstruir o horizonte de expectativas a partir do qual Auguste de Saint-Hilaire tece seu relato e constrói suas imagens. Compreender e expressar tais realidades exigiram que Saint-Hilaire recorresse tanto aos recursos de uma razão científica, que tudo queria registrar e catalogar, quanto ao sentimento típico de um artista paisagista que percebia e interpretava a realidade à sua maneira, segundo uma sensibilidade partilhada entre o autor e um nós, identificado com o público leitor.

Este lugar de fala, registrado pela sua identidade de naturalista e de viajante experimentado, propõe ao leitor o estabelecimento de uma autoridade inquestionável quanto aos julgamentos que faz. Uma longa viagem, a quantidade imensa de material coletado e doado às sociedades científicas, o cotejamento com a bibliografia disponível, a enumeração de dados e nomenclatura técnica submetem seu leitor ao pacto de autenticidade descritiva: "creia em mim, posto que minha fala é autorizada pela ciência". Evidentemente, esse pacto de autoridade delimita o horizonte de expectativas de uma sociedade orgulhosa e confiante em suas realizações. Mas esse pacto de autoridade vai muito além disso, na medida em que evoca a partilha de um campo de experiência e, principalmente, a autoria do escrito visto que seu modelo narrativo amparou-se nas expectativas projetadas sobre o viajante, e, mais especialmente, sobre o viajar e sobre os lugares percorridos.

Daí a complexidade do projeto de escrita de Saint-Hilaire. O autor está também sujeito ao repertório de temas e modelos narrativos de sua cultura, capazes de "ordenar, rearranjar e significar o trajeto de uma vida no suporte do texto, criando-se, através dele, um autor e uma narrativa" que, em última análise incide sobre a autoria efetiva da obra (Gomes, 2004, p. 19).

O produto imediato desse pacto de autoridade é o fortalecimento dos critérios de ordenação e explicação do mundo descrito. É exemplar desse processo de ordenação os caminhos percorridos pelo viajante. Os registros de Saint-Hilaire não testemunham apenas uma longa viagem. Registram também 
uma viagem que remete às estruturas econômicas diversificadas que compunham a paisagem econômica brasileira do início do século XIX: as lavouras de cana-de-açúcar, a mineração de ouro e diamantes e as recentes lavouras de café, no Vale do Paraíba, além de inúmeras culturas e modelos produtivos relatados ao longo de seus escritos. Tal registro polifônico indica, portanto, não apenas a pluralidade das atividades econômicas de distintas regiões, como também a diversidade de temporalidades que estavam incorporadas às distintas regiões de um território. Assim, apresentam-se no relato desde modelos produtivos fortemente associados ao mercado externo, como as províncias do Rio de Janeiro e São Paulo, passando pela frente de expansão que exercia forte atração demográfica e econômica tanto em Minas Gerais quanto em direção ao Sul do Brasil, mas também sociedades de afluência, caracterizadas pelos vínculos frágeis e esporádicos com o mercado, como o norte de Minas Gerais e Goiás.

À paisagem retratada - os povoados decadentes, a natureza exuberante, a população mestiça, a moralidade questionável - atribuiu-se um sentido mais profundo, cujas influências remontam ao pensamento fisiocrata, que temporalizou sua representação do espaço: o termo sertão adquiriu um telos que qualificou a experiência social por meio do que estaria por vir, a civilização. Além disso, expôs a dimensão subjetiva da experiência acumulada no interior do Brasil, uma vez que seu projeto de escrita foi claramente marcado por lembranças e sentimentos registrados ao longo dos anos necessários à realização desse empreendimento narrativo.

\section{Referências}

AMADO, Janaina. Região, sertão, nação. In.: Estudos históricos, vol.8, n¹5, 1995.

ARGAN, Giulio Carlo. Arte moderna. São Paulo: Companhia das Letras, 2010.

BELLUZO, Ana Maria de Moraes. O Brasil dos viajantes. $3^{\text {a }}$ edição. São Paulo: Metalivros, Rio de Janeiro: Editora Objetiva, 2000.

ARRAIS, Cristiano Alencar; SANDES, Noé Freire. História e memória em Goiás no século XIX. in. Vária Historia, vol. 29, n.51. Disponível em: http://www.scielo.br/pdf/vh/v29n51/v29n51a10.pdf Acesso em 23 de maio de 2016.

BIBLIOTECA NACIONAL (Brasil). Coleção Morgado de Mateus. Disponível em: http://bndigital.bn.gov.br/acervodigital. Acesso em 13 novembro 2018.

CAUDAS AULETE. Diccionário Contemporâneo da Língua Portugueza. Lisboa, Portugal: Imprensa Nacional, 1881. Disponível em: http://bibdig.biblioteca.unesp.br/handle/10/26034 Acesso em 15 de maio de 2016.

ECKARDT, Isadora. A perspectiva científica da literatura de viagem do século XIX: Auguste de SaintHilaire. In.: Estação literária. Vol.4, 2009.

FONSECA, Claudia Damasceno. Irregularidades ou pitorescas? Olhares sobre as paisagens urbanas mineiras. in. FURTADO, Júnia Ferreira (Org.). Sons, formas, cores e movimentos da modernidade atlântica: Europa, Américas e África. São Paulo: Annablume; Belo Horizonte: Fapemig; PPGH-UFMG, 2008.

FOUCAULT, Michel. A escrita de si. In: O que é um autor? Lisboa: Passagens. 1992.

GADENNE, Clotilde. Les voyageurs français et le concept de civilisation: un aspect paradoxal des échanges culturels entre France et Brésil (1822-1900). In: MATTOSO, Katia de Queirós, MUZARTFONSECA DOS SANTOS, Idelette, ROLLAND, Denis (dir.). Modeles politiques et culturels au Brésil: emprunts, adaptations, rejets XIXè et XXe siècles. Paris: Presses de l'Université de Paris-Sorbonne, 2003.

GARDINER, George. Viagem ao interior do Brasil. Belo Horizonte: Editora Itatiaia,1975.

HARTOG, François. O espelho de Heródoto: ensaio sobre a representação do Outro. Belo Horizonte: 
Editora UFMG, 1999.

HOBSBAWM, Eric. A era do capital. Rio de Janeiro: Paz e Terra, 1982.

JAUSS, Hans Robert. História da literatura como provocação à teoria literária. São Paulo: Ática, 1994.

KOSELLECK, Reinhart. 'Progress' and 'Decline': an appendix to the history of two concepts. In.: The practice of conceptual history. California: Stanford University Press, 2002.

KOSELLECK, Reinhart. Ponto de vista, perspectiva e temporalidade. In.: Futuro Passado. Rio de Janeiro: EDPUC, 2006.

KURY, Lorelai. Auguste de Saint-Hilaire, viajante exemplar. Intellectus, Vol. 2, n.1. 2003. Disponível em: http://www.intellectus.uerj.br/Textos/Ano2n1/Texto\%20de\%20\%20Lorelai\%20Kury.pdf Acesso em 10 de março de 2016.

KURY, Lorelai. Viajantes-naturalistas no Brasil oitocentista: experiência, relato e imagem. In.: História, ciências, saúde - Manguinhos, vol. VIII (suplemento), 863-880, 2001.

LIMA, Nisia Trindade. Um sertão chamado Brasil. Rio de Janeiro: IUPERJ, 1999.

LISBOA, Karen Macknow. A nova atlântida de Spix e Martius: natureza e civilização na viagem pelo Brasil (1817-1820). São Paulo: Huicitec, 1997.

MARCIL, Yasmine. A viagem de Saint-Hilaire ao Brasil na revista Nouvelles Annales des voyges. in.: SARTHOU, Corinne; PIGNAL, Marc; ROMANIUC-NETO, Sergio; LAMY, Denis (Coord.). Auguste de SaintHilaire, um botânico francês no Brasil. Paris, França: Muséum National d'Histoire Naturelle, 2016.

MIRANDA, Luiz Francisco Albuquerque de. Viajantes do início do século XIX e a representação do sertão brasileiro. In.: Anais do X Simpósio Internacional Processo Civilizador. 2007. Disponível em: http://docplayer.com.br/11987471-Viajantes-do-inicio-do-seculo-xix-e-a-representacao-do-sertaobrasileiro-resumo.html Acesso em 10 de março de 2016.

MIRANDA, Luiz Francisco Albuquerque. O deserto dos mestiços: o sertão e seus habitantes nos relatos de viagem do início do século XIX. História, n.28, 2009. Disponível em: http://www.scielo.br/scielo.php?script=sci_arttext\&pid=S0101-90742009000200021\&lng=pt\&tlng=en Acesso em 10 de março de 2016.

MORAES, Antonio Robert. O sertão, um ‘outro'geográfico. in.: Terra brasilis (nova série), n4/5, 2003.

PINTO, Luiz Maria da Silva. Dicionário da Lingua Brasileira. Ouro Preto, MG: Typographia de Silva, 1832.

POHL, Johann Emanuel. Viagem no interior do Brasil. Belo Horizonte: Editora Itatiaia, 1976.

PRATT, Mary Louise. Os olhos do império: relatos de viagem e transculturação. Bauru: EDUSC, 1999.

PRIETO, Adolfo. Los viajeros ingleses y la emergencia de la literatura argentina (1820-1850). Buenos Aires, Argentina: Fondo de Cultura Economica, 2003

SAINT-HILAIRE, August de. Viagens à Província de Goiás. Tradução: Regina Regis Junqueira. Belo Horizonte: Ed. Itatiaia; São Paulo: EDUSP, 1975.

SAINT-HILAIRE, Auguste de. Viagem à Província do Rio de Janeiro e Minas Gerais. 1975.

SAINT-HILAIRE, Auguste de. Viagem à Província de São Paulo. São Paulo: Livraria Editora Martins Editora, 1945.

SALLAS, Ana Luisa Fayet. Ciência do homem e sentimento da natureza: viajantes alemães no Brasil do século XIX. Paraná: Editora UFPR, 2013. 
SARTHOU, Corinne; PIGNAL, Marc; ROMANIUC-NETO, Sergio; LAMY, Denis. Augute de Saint-Hilaire, o botânico através de sua correspondência. in.: SARTHOU, Corinne; PIGNAL, Marc; ROMANIUC-NETO, Sergio; LAMY, Denis (Coord.). Auguste de Saint-Hilaire, um botânico francês no Brasil. Paris, França: Muséum National d’Histoire Naturelle, 2016.

SOUZA, Candice Vidal. A pátria geográfica: sertão e litoral no pensamento social brasileiro. Goiânia: Editora UFG, 1997.

SPIX e MARTIUS. Viagem pelo Brasil (1817-1820). Belo Horizonte: Ed. Itatiaia; São Paulo: EDUSP, 1975.

SÜSSEKIND, Flora. O Brasil não é longe daqui. São Paulo: Cia. das Letras, 1990.

TAUNAY, Alfredo de Escrangnolle. A província de Goyaz na Exposição Universal. 1876. Disponível em: www.brasiliana.usp.br Acesso em 17 de maio de 2016.

TORRÃO FILHO, Amilcar. A arquitetura da alteridade: a cidade-brasileira na literatura de viagem (17831845) (Tese de Doutorado), Campinas, SP: Unicamp, 2008.

VERSIANI, Flávio Rabelo. Os escravos que Saint-Hilaire viu. In.: História Econômica e Economia de Empresas 3(1):7-42, 2000.

\section{Notas de autoria}

Cristiano Alencar Arrais é doutor em História. Professor Associado de Teoria da História e do Programa de Pós-Graduação em História da Universidade Federal de Goiás. E-mail: cpaarrais@gmail.com.

Deusa Maria Boaventura é doutora em Arquitetura e Urbanismo. Professora Adjunto do Programa de PósGraduação em História da Pontifícia Universidade Católica de Goiás. E-mail: dmrbester@gmail.com.

\section{Como citar esse artigo de acordo com as normas da revista}

ARRAIS, Cristiano Alencar Arrais; BOAVENTURA, Deusa Maria. Modelo narrativo e composição da paisagem em Voyage à l'interieur du Brésil. Sæculum - Revista de História, v. 24, nº 41, p. 111-123, 2019.

\section{Contribuição de autoria}

Não se aplica.

\section{Consentimento de uso de imagem}

Não se aplica.

\section{Aprovação de comitê de ética em pesquisa}

Não se aplica.

\section{Financiamento}

Este artigo é o produto de projeto de pesquisa "Cultura Material e historiografia de Goiás", financiado pela Fundação de Apoio à Pesquisa do Estado de Goiás (FAPEG) por meio do Edital 005/2012.

\section{Licença de uso}

Este artigo está licenciado sob a Licença Creative Commons CC-BY. Com essa licença você pode compartilhar, adaptar, criar para qualquer fim, desde que atribua a autoria da obra.

\section{Histórico}

Recebido em 30/03/2019.

Aprovado em 25/11/2019. 